\title{
Growth performance of Clarias gariepinus fingerlings fed diets containing varying levels of groundnut oil
}

\author{
Victor Tosin Okomoda ${ }^{1^{*}}$ - Lateef Oloyede Tiamiyu ${ }^{2}$ - Ronald Terhile Chado ${ }^{1}$ \\ ${ }^{1}$ Department of Fisheries and Aquaculture, University of Agriculture Makurdi, Nigeria \\ 2 Department of Aquaculture and Fisheries, University of Ilorin, Kwara State, Nigeria \\ *Corresponding author: okomodavictor@yahoo.com
}

How to cite this paper:

Okomoda, V.T., Tiamiyu, L.O. \& Chado, R.T. (2017) Growth performance of Clarias gariepinus fingerlings fed diets containing varying levels of groundnut oil.

Ege Journal of Fisheries and Aquatic Sciences, 34(1): 111-114. doi:10.12714/egejas.2017.34.1.15

Abstract: The effect of varying levels of groundnut oil was assessed on growth of African catfish. Fingerlings with mean weight $1.87 \mathrm{~g}$ were stocked at 20 fish per hapa (measuring $1 \mathrm{~m} \times 1 \mathrm{~m} \times 1 \mathrm{~m}$ ) and fed five $35 \%$ Crude protein diets formulated with groundnut oil (GO) included at $0.00 \%, 2.50 \%, 5.00 \%, 7.50 \%$ and $10.00 \%$. After eight weeks of feeding, result shows evidence of the fact that increasing lipid level spared dietary protein conversion into energy as $\mathrm{GO}$ inclusion significantly performed better than the control without GO, however, performance was optimized at $2.50 \% \mathrm{GO}$ inclusion in the diet, beyond this growth significantly reduced.

Keywords: Lipid, ether extract, growth performance, nutrient utilization, nutrient sparing

\section{INTRODUCTION}

Every living organism including fish requires food for growth, reproduction and maintenance of tissues. To sustain fish under culture, supplementation diet must be provided to complement natural feeds supply (Karapan Agbottidis, 2002). Feed stuffs used in aquaculture to provide basic nutrients such as protein, carbohydrate, minerals, water, vitamins and lipids are expensive because of their competitive uses by man and other animals (Dunham et al., 2001). Research has therefore focused on the need to provide alternative sources of these essential nutrients for use in aqua-feeds.

Lipids are highly digestible source of concentrated energy and contain about 2.25 times as much energy as equivalent amount of carbohydrates (Robinson et al., 2001) and proteins (Sotolu, 2010). Lipids comprise about $15 \%$ fish diet and supply essential fatty acid (EFA) as well as serves as transport for fat soluble vitamins (Lim et al., 2001). Fish oil is generally used as the main source of fatty acid in commercial fish diets and in most nutrition studies. It is produced from small pelagic fish and represents a finite fishery resource ( $\mathrm{Ng}$ et al., 2003), the demand for fish and fish oil by aqua feeds industry wasexpected to exceed the production capacity as at 2000 (Barlow and Pike, 1999), however, It was estimated to be about $60 \%$ of the global supply of fish oil as opined by Barlow et al., (2000) and as much as $90 \%$ use of total consumption was projected for 2010 (Barlow et al., 2000). The consequence of this is literarily increase in the cost of fish oil as well as aquaculture feed, hence, the need to intensify efforts to replace fish oil with other lipid sources (Aderolu and Akinremi, 2009).
Worldwide, natural vegetable or plant oil sources and fat are increasingly becoming important in nutrition and commercial feed production because of possession of high dietary energy, essential fatty acids, biofuels, anti-oxidants and raw-material for the manufacture of industrial products. (Okullo et al., 2010). Previous research have focused attention onthe use of oil seeds such as groundnut oil, benniseed(sesame), shea butter oil, cotton seeds and palm oil as suitable substitutes in the diet of warm water fish species (Legendre et al., 1995; $\mathrm{Ng}$ et al., 2000; $\mathrm{Ng}$ et al., 2003; Ochang et al., 2007; Yusuf 2009; Aderolu and Akinremi, 2009; Solomon et al., 2012) and reported positive result.Currently, the use of groundnut oil in aqua feeds is estimated to be as low as 0.8 million tons of $61 \%$ global oil produced (Goda et al., 2007) and expected to increase in the near future. It is however important to note that high lipid content of fish diet improves growth rate and protein utilization but predisposes feed to rancidity; the consequentof which islower fish performance due to lipids oxidation (Scaifedet et al., 2000). The level of oil is largely dependent on the lipid source. used in feed formulation. This study is therefore designed to determine best level of inclusion of groundnut oil in the diet of African catfish.

\section{MATERIALS AND METHODS}

The feeding trial was carried out at the Fisheries experimental farm sited in South Core, University of Agriculture, Makurdi, Benue State Nigeria.Three hundred (300) fingerlings of Clarias gariepinus were obtained from the University 
hatchery and acclimatized for 2 weeks. During the period of acclimatization, the fish were fed with $0.2 \mathrm{~mm}$ Coppen feed. Fifteen hapa-nets were constructed and arranged in an earthen pond for the feeding trial. The fingerlings were randomly distributed in 20 numbers to all hapas unit.

Feed ingredient used for the feed formulation (Fish meal, soybean meal, Groundnut oil, Maize meal, Rice bran, Salt, Vitamin and Mineral premixes) were purchased from Modern market Makurdi, Nigeria. The feed stuffs/ingredients were processed to improve their digestibility and eliminate antinutritional factor that may be present in the feed (Table 1).

Table 1. Percentage composition of experimental diet using Pearson's Square method

\begin{tabular}{llllll}
\hline Ingredient\% & Diet 1 & Diet 2 & Diet 3 & Diet 4 & Diet 5 \\
\hline Fish meal & 10.00 & 10.00 & 10.00 & 10.00 & 10.00 \\
Soybean meal & 50.72 & 51.06 & 51.82 & 52.56 & 53.30 \\
Groundnut oil & 0.00 & 2.50 & 5.00 & 7.50 & 10.00 \\
Maize meal & 33.28 & 30.44 & 27.18 & 23.94 & 20.70 \\
Rice bran & 5.00 & 5.00 & 5.00 & 5.00 & 5.00 \\
Salt & 0.50 & 0.50 & 0.50 & 0.50 & 0.50 \\
Mineral Premix* & 0.25 & 0.25 & 0.25 & 0.25 & 0.25 \\
Vitamin Premix & 0.25 & 0.25 & 0.25 & 0.25 & 0.25 \\
\hline Total & 100.00 & 100.00 & 100.00 & 100.00 & 100.00
\end{tabular}

*contain (as mg kg-1 of diet): Thiamine (B1), 85.00; Riboflavin (B2), 60.00; Pyridoxine (B6), 25.00; Pantothemic acid, 105.00; Inositol, 500.00; Biotin, 1.80 Folic acid, 20.00; Ethoxyquin, 4.00; Choline, 1481.00; Nicotinic acid (Niacin) 250.00; Cyanocobalamin (B12), 0.03; Retinol palmitate (A), 20.00; Tocopherol acetate (E), 140.00; Ascorbic acid (C), 750.00; Menadione (K), 30.00 Cholecalciferol (D3), 0.08 (according to Jauncey and Ross 1982)

${ }^{* *}$ Contained (as g kg-1 of diet): MgSO4,7H2O, 20.40; NaCl, 8.00; KCl, 6.04 $\mathrm{FeSO} 4,7 \mathrm{H} 2 \mathrm{O}, 4.00 ; \mathrm{ZnSO} 4,4 \mathrm{H} 2 \mathrm{O}, 0.88$; $\mathrm{MnSO} 4.4 \mathrm{H} 2 \mathrm{O}, 0.41$; CuSO4,5H2O $0.13 ; \mathrm{CoSO} 4,7 \mathrm{H} 2 \mathrm{O}, 0.08 ; \mathrm{CalO} 3,6 \mathrm{H} 2 \mathrm{O}, 0.05 ; \mathrm{CrCl} 3,6 \mathrm{H} 2 \mathrm{O}, 0.02$ (according to Jauncey and Ross 1982)

Five diets of $35 \%$ crude protein were formulated with $0.00 \%, 2.50 \%, 5.00 \%, 7.50 \%$ and $10.00 \%$ levels of groundnut oil to distinguished the different diets into Diet 1, Diet 2, Diet 3, Diet 4 and Diet 5 respectively (Table 2).

Table 2. Proximate composition of the diets containing different levels of groundnut oil

\begin{tabular}{lcccccc}
\hline Parameter & Diet 1 & Diet 2 & Diet 3 & Diet 4 & Diet 5 & SEM \\
\hline Moisture & $6.03^{\mathrm{c}}$ & $7.23^{\mathrm{c}}$ & $7.38^{\mathrm{b}}$ & $7.16^{\mathrm{d}}$ & $7.57^{\mathrm{a}}$ & 0.12 \\
Crude & 35.13 & 35.87 & 36.75 & 36.51 & 35.74 & 1.31 \\
Protein & & & & & & \\
Crude Fibre & $4.02^{\mathrm{b}}$ & $4.11^{\mathrm{a}}$ & $3.77^{\mathrm{c}}$ & $3.62^{\mathrm{d}}$ & $3.77^{\mathrm{c}}$ & 0.91 \\
Lipids & $8.81^{\mathrm{c}}$ & $11.19^{\mathrm{d}}$ & $12.12^{\mathrm{c}}$ & $13.06^{\mathrm{b}}$ & $13.18^{\mathrm{a}}$ & 2.06 \\
Ash & $6.03^{\mathrm{d}}$ & $6.21^{\mathrm{c}}$ & $6.33^{\mathrm{b}}$ & $6.24^{\mathrm{c}}$ & $6.49^{\mathrm{a}}$ & 0.71 \\
NFE & $40.00^{\mathrm{a}}$ & $35.40^{\mathrm{b}}$ & $33.66^{\mathrm{c}}$ & $33.41^{\mathrm{d}}$ & $33.27^{\mathrm{e}}$ & 1.23 \\
\hline
\end{tabular}

Mean in the same row with different superscript differ significantly $(P>0.05)$ means were separated using Fisher's least significant difference

Fish were fed for eight weeks at $10 \%$ of their body weight; the amount of feed given was adjusted after the weekly measurement. The growth parameter was estimated as given below.

a. Mean Initial Weight $(\mathrm{MIW})=\frac{\text { Total Initial Weight of Fingerlings }}{\text { Total Number of Fingerlings }}$ b. Mean Weight Gain $(M W G)=$ Mean final weight - Mean initial weight

c. Growth rate $=\frac{\text { Mean final weight }- \text { Mean Initial Weight } X 100}{\text { Duration }}$

d. Specific Growth Rate (\%/day) $=\frac{\log _{e}\left(w t_{2}\right)-\log _{e}\left(w t_{1}\right)}{t_{2-t_{1}}}$

Where $\mathrm{Wt}_{1}=$ Initial weight gain

$\mathrm{Wt}_{2}=$ Final weight gain

$\mathrm{T}_{2}-\mathrm{T}_{1}=$ Duration (in days) considered between $\mathrm{Wt}_{2}$ and $\mathrm{Wt}_{1}$

e. Feed Fed $(\mathrm{FF})=\frac{\text { Sum of Total feedintake per week }}{\text { Number of fish }}$

f. Feed conversion ratio $(F C R)=\frac{\text { dryfeedintake }}{\text { wetweightgain }}$

g. Feed Efficiency ratio $(\mathrm{FER})=\frac{\text { wetweightgain } \times 100}{\text { dryfeedintake }}$

h. Protein efficiency ratio $=\frac{\text { wetweightgain }}{\text { proteinfed }}$

Where Protein fed $=\frac{\% \text { proteinindiet } \times \text { totaldietconsumed }}{100}$

i. $\%$ survival rate $=\frac{\text { totalnumberoffish-mortality }}{\text { totalnumberof fish }} \times 100$

The proximate composition of the diet formulated and the proximate composition of the initial and final carcass of the experimental fish were determined according to methods described by AOAC (2000). Statistical analysis was carried out using analysis of variance and where there were significant differences Fishers least significant difference were used to separate means. These analyses were performed using the Minitab 14 software.

\section{RESULTS AND DISCUSSION}

The use of ground nut oil (GO) in the diet of Clarias gariepinus significant improve growth performance and nutrient utilization of African catfish in this study as the various diet with inclusion levels of GO performed better than the control diet without GO (Table 3). This may have been due to non-protein energy source provided by the GO for metabolism, hence, allowing the use of the protein/carbohydrate component of the feed for growth and development. It may be inferred that increased lipid level spared dietary protein conversion into energy (Chou and Shiau, 1996; Regost et al 2003. Non-protein source of energy has been reported to influence nitrogen retention and dietary lipid, hence affecting positively growth, protein utilization, and feed conversion efficiency (Pie et al 2004), this is in line with the observation of this study, Peres and Oliva-Teles (1999) however did not observe any protein sparing effect of lipid when they fed European Zea bass on graded levels of dietary lipid. Solomon et al (2012) had earlier concluded that plant based lipid diets such as groundnut oil, palm oil, and Soya oil are well utilized by Clariasgariepinus which was confirmed in this study. Also,plant lipid sources have been reported to be good natural source of carotenoids, tocopherols and tocotrienols which function as natural antioxidant, hence conferring beneficial effects on growth and flesh quality (Lim et al., 2001), Lim et al (2001) reported up to $8 \%$ refined bleached and deodorize palm oil to improved performance, protein retention and fillet vitamin $\mathrm{E}$ concentration of the African catfish, however this study reveal that African 
catfish can tolerate up to $10 \%$ GO and still give better result than control diet.

Many previous study on lipid sources had focused on identifying suitable substitute for fish oil (Legendre et al., 1995; Varghese and Oommen, 2000; Rosenlund et al., 2001; Bell et al., 2002; Ng et al., 2003, Aderolu and Akinremi, 2009) without considering acceptable level of inclusion in which addition may be detrimental to fish. Despite better growth linked to the addition of GO compared to control diet, this study observed significant decline in growth at levels beyond $2.50 \%$ inclution of GO, Scaifed et al., (2000) has reported that high dietary lipid in feed make growth lower in fish due to lipids oxidation.The increase in feed conversion ratio FCR with increasing GO level is an indication of higher dietary requirement to attain $1 \mathrm{~kg}$ of flesh, this is in agreement with reported works of Einen and Roem (1997); Weatherup et al., (1997) and Pie et al., (2004). Despite better growth observed with the addition of GO compared to control diet, decrease in protein efficiency ratio with increasing high lipid levels was a fundamental observation in this study, this is in agreement with previous studies by Einen and Roem (1997), Weatherup et al., (1997), Pie et al., (2004) and Aderolu and Akinremi, (2009). There was no observed problem with palatability and digestibility as the amount of feed fed for diet with GO was significantly higher than the control, this observation is supported by the woks of Aderolu and Akinremi (2009) on the utilization of coco-nut oil and pea-nut oil in catfish feed. Also Sotolu (2010) reported similar findings when fingerlings of Clarias gariepinus were fed diet containing beneseed oil.

Protein content of fish fed diet containing $2.50 \%$ GO was higher $(14.89 \pm 0.11)$ compared with fish fed diet with higher levels of GO (Table 4). Although Bell et al., (2002) and $\mathrm{Ng}$ et al., (2003) had reported that use of high levels of palm oil in fish diets decrease the concentrations of beneficial omega-3 HUFA and general fat content in fish fillets, the observation of this study was contrary to this hypothesis as lipid accumulate more despite lower growth in fish fed above $2.50 \% \mathrm{GO}$. Caballero et al., (2004) had reported that the reduction of dietary essential fatty acids due to the inclusion of vegetable oils in the diets of fish tends to promote fat accumulation in the liver of sea bream. Babalola and Adebayo, (2007) however, reported that lipid, ash, protein, crude fibre, and moisture composition of Heterobranchussp. fed different levels of Palm oil were not statistically different after 8 weeks. Inverse relation between body protein and lipid content was observed in this study and is in accordance with reported works by Jokumsen and Aisted, (1990); Bell et al., (2002) in Salmonids and by Babalola and Adebayo, (2007).

Conclusively, fingerlings of Clarias gariepinus were able to utilize higher levels of groundnut oil effectively up to $10 \%$ level of inclusion, however optimally growth performed of Clarias gariepinus was at $2.5 \% \mathrm{GO}$ in the diet, optimal levels of various other vegetable sources of dietary lipid may be tested to provide suitable alternative for aqua feed

Table 3. Growth performance and nutrient utilization of clarias gariepinus fingerlings fed diets containing varying levels of groundnut oil

\begin{tabular}{|c|c|c|c|c|c|c|}
\hline Parameter & Diet 1 & Diet 2 & Diet 3 & Diet 4 & Diet 5 & SEM \\
\hline Mean Initial Weight & 1.87 & 1.84 & 1.86 & 1.86 & 1.85 & 0.003 \\
\hline Mean Final Weight & $3.37 \mathrm{e}$ & $3.73^{a}$ & $3.62^{b}$ & $3.47^{c}$ & $3.44^{d}$ & 0.23 \\
\hline Mean weight gain & $1.51^{\mathrm{e}}$ & $1.89^{a}$ & $1.76^{b}$ & $1.62^{c}$ & $1.56^{d}$ & 0.04 \\
\hline Mean growth rate & $0.027^{c}$ & $0.034^{a}$ & $0.031^{a b}$ & $0.028 b c$ & $0.029 b c$ & 0.005 \\
\hline SGR & $1.046^{d}$ & $1.26^{a}$ & $1.19^{b}$ & $1.11^{c}$ & $1.11^{c}$ & 0.02 \\
\hline Feed fed & $7.05^{c}$ & $7.79^{a}$ & $7.67^{b}$ & $7.64^{b}$ & $7.64^{b}$ & 0.81 \\
\hline FCR & $5.10^{a}$ & $4.13^{e}$ & $4.38^{d}$ & $4.72^{c}$ & $4.79^{b}$ & 1.09 \\
\hline FCE & $21.75^{\mathrm{e}}$ & $24.24^{a}$ & $22.15^{b}$ & $21.15^{c}$ & $20.91^{d}$ & 0.02 \\
\hline PER & $0.043^{d}$ & $0.054^{a}$ & $0.05^{b}$ & $0.05^{b}$ & $0.046^{c}$ & 0.001 \\
\hline ANPU & $11.61^{d}$ & $18.35^{a}$ & $17.63^{b}$ & $13.11^{\mathrm{c}}$ & $10.61^{d}$ & 0.23 \\
\hline$\%$ Survival rate & $57.5^{\mathrm{a}}$ & $75.0^{c}$ & $67.5^{\mathrm{b}}$ & $67.5^{b}$ & $67.5^{b}$ & 3.02 \\
\hline
\end{tabular}

Mean in the same row with different superscript differ significantly $(P>0.05)$, means were separated using Fisher's least significant difference

Table 4. Proximate composition Carcass before and after feeding with diets containing different levels of groundnut oil

\begin{tabular}{llllllll}
\hline \multicolumn{1}{c}{ Parameter } & Initial & Diet 1 & Diet 2 & Diet 3 & Diet 4 & Diet 5 & SEM \\
\hline Moisture & $78.13^{\mathrm{a}}$ & $66.35^{\mathrm{b}}$ & $64.35^{\mathrm{b}}$ & $63.10^{\mathrm{d}}$ & $64.73^{\mathrm{c}}$ & $64.87^{\mathrm{c}}$ & 0.002 \\
Protein & $8.46^{\mathrm{a}}$ & $12.3^{\mathrm{d}}$ & $14.89^{\mathrm{a}}$ & $14.63^{\mathrm{b}}$ & $13.05^{\mathrm{c}}$ & $12.18^{\mathrm{e}}$ & 2.03 \\
Fat & $6.87^{\mathrm{e}}$ & $7.03^{\mathrm{d}}$ & $8.40^{\mathrm{c}}$ & $9.76^{\mathrm{b}}$ & $10.04^{\mathrm{a}}$ & $10.08^{\mathrm{a}}$ & 1.42 \\
Fibre & $2.00^{\mathrm{e}}$ & $2.02^{\mathrm{d}}$ & $2.56^{\mathrm{a}}$ & $2.37^{\mathrm{b}}$ & $2.12^{\mathrm{c}}$ & $2.04^{\mathrm{d}}$ & 0.003 \\
Ash & $2.84^{\mathrm{a}}$ & $2.07^{\mathrm{f}}$ & $2.64^{\mathrm{b}}$ & $2.43^{\mathrm{c}}$ & $2.35^{\mathrm{d}}$ & $2.12^{\mathrm{e}}$ & 0.02 \\
NFE & $7.80^{\mathrm{b}}$ & $6.70^{\mathrm{c}}$ & $5.72^{\mathrm{d}}$ & $7.71^{\mathrm{b}}$ & $7.71^{\mathrm{b}}$ & $8.71^{\mathrm{a}}$ & 1.53 \\
\hline
\end{tabular}

Mean in the same row with different superscript differ significantly $(\mathrm{P}>0.05)$, means were separated using Fisher's least significant difference 


\section{REFERENCES}

A. O. A. C. (Association of Official Analytical Chemists) (2000). Official methods of analysis $16^{\text {th }}$ edition, Arlington Virginia, USA.

Aderolu, A.Z. \& Akinemi, O.A. (2009). Dietary effects of coco-nut oil and peanut oil in improving biochemical characteristic of Clarias gariepinus (juvenile). Turkish Journal of Fisheries and Aquatic Science. 9:105-110.

Babalola, T.O. \& Adebayo, M.A. (2007). Effects of dietary lipid level on growth performance and feed utilization of Heterobranchus longifilis fingerlings, Journal of Fisheries International, 2:60-64. doi: jish.2007.60.64

Barlow, S. (2000). Fishmeal and oil: Sustainable feed ingredients for aquafeeds. Global Aquaculture Advocate. 4: 85-88

Barlow, S.M. \& Pike, I.H. (1999). Aquaculture feed ingredient in year 2010. In: C.E, Nash and V. Julian (Eds). Fish meal and fish oil. In report Aquavision 98. Nutreco Aquaculture, c/o skretting As, Stavanger, Norway. 71 -72

Bell, J.G., Henderson, R.J., Tocher, D.R., Mc Ghee, F., Dick, J.R., Potter, A., Smullen, R.P. \& Sargent, J.R. (2002). Substituting fish oil with crude palm oil in the diet of Atlantic salmon (Salmo salar), effects on the muscle fatty acid composition and hepatic acid metabolism. Journal of Nutrition. 132 220-230. Available at http://jn.nutrition.org/content/132/2/222.full.pdf+html

Caballero, M.J., Izquierdo, M.N., Kjorvik, E., Fernandez, A.J. \& Rosenland, G. (2004). Histological alteractions in the liver of sea bream Sparus aurata $L$ caused by short or long term feeding with vegetable oil. Recovery of normal morphology alter feeding fish oil as the sole lipid source. Journal of Fish Disease.27:531. doi: 10.1111/j.1365-2761.2004.00572.x

Chou, B.S. \& Shiau, S.Y. (1996). Optimal dietary lipid level for growth in juvenile hybrid tilapia Oreochromis niloticus $X$ Oreochromis aureus. Aquaculture. 143: 185-195. doi: 10.1016/0044-8486(96)01266-5

Dunham, R.A., Majumdar, K., Hallerman, E., Bartly, D., Mair, G., Hulata, G. Liu, Z., Pongthan, N., Bakos, J., Penman, D., Gupta, M., Rothlisberg, P. \& Hoerstgen-Schwark, G. (2001). Review of the status of aquaculture genetics. In: R. P. Subasinghe P, Bueno MJ, Philips C, Hough SE, Mc Gladdeny \& JR Arthur (Eds). Aquaculture in the third millennium. Technical proceeding of the conference on aquaculture in the third millennium, Bangkok, Thailand, 20-25 February, 2000 PP137-166.NACA Bangkok and FAO, Rome.

Einen, O. \& Roem, A.J. (1997). Dietary protein/ energy ratios for Atlantic salmon in relation to fish size, growth, feed utilization and slaughter quality. Aquaculture Nutrition, 3: 115-126. doi: 10.1046/j.1365-2095.1997.00084.x

Goda, A.M., El, A.S., Haroun, E.R. \& Kabirchowdhury, M.A. (2007). Effect of totally or partially replacing of fish meal by alternative protein source in growth of African catfish Clarias gariepinus (Burchell,1822) reared in concrete tanks: Aquaculture Research 38: 229-287. doi: 10.1111/j.1365-2109.2007.01663.x

Jokumsen, A.\& Aisted, N. (1990). Orredvaekst 1 relation til forholdet mellem protein og fedt 1 foderet. Medd. Forsogsdambruget. 80: 1-15.

Karapan, A. (2002). Studies to optimize poly unsaturated fatty acid composition of tilapia for human consumption in S.E. Asia. Aquaculture News.28:6-7.

Legendre, M., Kerdchuan, N., Corraze, G. \& Bergot, P. (1995). Larval rearing of an African catfish, Heterobranchus longifilis Teleostei, Clariidae: effect of dietary lipid son growth, survival and fatty acid composition of fry. Aquatic Living Resources. 8: 355-363. doi: 10.1051/alr:1995040

Lim, P.K., Boey, P.L. \& Ng, W.K. (2001). Dietary palm oil level effects on growth performance, protein Retention and Tissue Vitamin E Concentration of African catfish Clarias gariepinus. Aquaculture. 202:101-102. doi: 10.1016/S0044-8486(01)00563-4

Ng, W.K. Tee, M.C. \& Boey, P.L. (2000). Evaluation of crude palm oil and refined palm oil as dietary lipids in pelletized feeds for a tropical bagrid catfish, Mystus nemurus (Cuvier \& Valendciennes). Aquaculture Research, 31:337-347. doi: 10.1046/j.1365-2109.2000.00437.x

Ng, W.K. Lim, P.K. \& Boy, P.L. (2003). Dietary palm oil source affects growth fatty acid composition and muscle X-tocopherol concentration of African catfish (Clarias gariepinus). Aquaculture. 215:229-243.

doi: 10.1016/S0044-8486(02)00067-4

Ochang, S.N., Fagbenro, O.A. \& Adebayo, O.T. (2007). Influence of dietary palm oil on growth response, carcass composition, haematology and organoleptic properties of juvenile Nile tilapia, Oreochromis niloticus. Pakistan Journal of Nutrition, 6: 424-429. Available at http://docsdrive.com/pdfs/ansinet/pjn/2007/424-429.pdf

Okullo, J.B.L., Omujar, F., Agea, J.G., Vuzi, P.C., Namutebi, A., Okelle, J.B.A. \& Nyanzi, S. A. (2010). Physio-chemical characteristic of shea-butter (Vitellaria paradoxa, C.F. Gaertin) oil from shea-districts of Uganda. African Journal of Food Agriculture, Nutrition and Development 10:1-15. doi: 10.4314/ajfand.v10i1.51484

Peres, H. \& Olivia-Teles, A. (1999). Effect of dietary lipid level on growth performance and feed utilization by European sea bass juvenile (Dicentarchus labrax). Aquaculture, 179: 325-334. doi: 10.1016/S0044-8486(99)00168-4

Pie, Z., Xhu X. \& Yang, Y. (2004). Comparative Study on the Effect of Dietary Lipid level on Growth and Feed Utilization for Gibel carp (Carcasius auraatus Gibelio) and Chinese long snout catfish (Leiocassius logirostris, Gunther). Aquaculture Nutrition. 10:209-216. doi: 10.1111/j.1365-2095.2004.00291.x

Regost, C., Arzel, J., Robien, J., Roseland, G. \& Kaushik, S.J. (2003). Total replacement of fish oil by soybean or linseed oil with a return to fish oil in turbot growth performance. Flesh fatty acid profile and lipid metabolism. Aquaculture, 217:465-4820. doi: 10.1016/S0044-8486(02)00259-4

Robinson, Z.H., Menghe, H.L. \& Manning, B.B. (2001). A practical guide to nutrition, feed and feeding of catfish. MiSSiPPi State University Publication No.1113, 39 pp.

Rosenlund, G., Obach, A., Sandberg, M. G., Standal, H. \& Tveit, K. (2001), Effect of alternative lipid sources on long term growth performance and quality of Atlantic salmon (Salmo salar L.). Aquaculture Research. 32: 323328. doi: 10.1046/j.1355-557x.2001.00025.x

Scaifed, J.R.G.E., Murray, I., Fletcher, T.C. \& Henlihan, D.F. (2000). Influence of a-tocoferolacetate on the short and long-term storage properties of fillets from Atlantic salmon (Salmon salar) fed high lipid diet. Aquaculture Nutrition. 6:65-71. doi: 10.1046/j.1365-2095.2000.00128.x

Solomon, S.G., Ataguba, G.A. \& Imbur, L, (2012). Growth Performance of Juvenile of Clarias gariepinus Fed Different Lipid Sources. International Journal of Research In Fisheries and Aquaculture. 2:52-55.

Sotolu, A.O. (2010). Feed utilization and biochemical characteristics of Clarias gariepinus (Burchell,1822) fingerlings feed diet containing fish oil vegetable oil as total replacements. World Journal of Fish and Marine Science, 2:93-98. Available at http://idosi.org/wjfms/wjfms2(2)10/4.pdf

Varghese, S. \& Oommen, O.V. (2000). Long-term feeding of dietary oils alters lipid metabolism, lipid peroxidation and antioxidant enzyme activities in a teleost (Anabas testudineus Bloch). Lipids. 35:757-762. doi: $10.1007 / \mathrm{s} 11745-000-0582-2$

Weatherup, R.N., Mc Cracken, K.J., Foy, R., Rice, D., Mc Kendry, J., Mairs, R.J. \& Hoey, R. (1997). The effects of dietary fat content on performance and body composition of farmed rainbow trout (Oncorhyncus mykiss). Aquaculture, 151: 173- 184. doi: 10.1016/S0044-8486(96)01507-4

Yusuf, A.M., Olafadehan, O.A., Obun, C.O., Inuwa, M., Garba, M.H. \& Shagwa, S.M. (2009). Nutritional evaluation of Shea butter fat in fattening of Yankassa sheep. Pakistan Journal of Nutrition. 8: 1062-1067. 